\title{
Investigating the Challenges Faced by Women Rice Farmers in Nigeria
}

\author{
Ojinga Gideon Omiunu1,2 \\ ${ }^{1}$ Africa Regional Centre for Information Science, University of Ibadan, Ibadan, Nigeria \\ ${ }^{2}$ Unicorn Academics and Organisation, Developmental Research Centre, Ibadan, Nigeria \\ Email: ohiojingao@yahoo.com, omiunuojingag@gmail.com
}

Received 8 July 2014; revised 10 August 2014; accepted 15 September 2014

Copyright (C) 2014 by author and OALib.

This work is licensed under the Creative Commons Attribution International License (CC BY).

http://creativecommons.org/licenses/by/4.0/

(c) (i) Open Access

\begin{abstract}
The study investigated the major constraints faced by women rice farmers in Nigeria. The study employed a survey research design. One hundred women rice farmers were randomly selected and information were obtained with the aid of well-structured questionnaire. The frequency, percentage, t-test and regression analysis were used to analyze data obtained. The study revealed that, only $26 \%$ had negative productivity, $53 \%$ had positive productivity, few $(31 \%)$ had a positive profit of above 100,000 Naira and others have a profit of between 1 - 100,000 Naira. Personal saving was the best source of finance or capital for women rice farmers. Lack of finance is one of the major challenges faced by women rice farmers. Other challenges include credit availability and accessibility, lack of mechanized/technological equipments, level of degradation, among others. Also, result showed that only government support as a source of finance was negatively significant and affected women rice farmers' productivity negatively. The study recommended that, women rice farmers should endeavour to undergo various developmental programmes to develop themselves so as to increase their competitive advantage in their locality and also in the local and global agricultural sector. In addition, governments and other policy makers should strategize plans and programmes that would contribute to women rice farmers, agriculture, community and national development.
\end{abstract}

\section{Keywords}

Nigeria Women Rice Farmers, Challenges of Women Rice Farmers

Subject Areas: Agricultural Science, Business Analysis

\section{Background to the Study}

In developing economies, such as Nigeria, Rice (Oryza sativa) is a major staple food [1] for millions of people, 
the fastest growing commodity in Nigeria's food basket [2] and is cushioning the effect of under-nutrition and severe hunger among many households as it is commonly eaten in many localities and processed into different forms. The Nigeria population according to the Nigerian Population Census was approximately 150 million and the Nigeria domestic economy is predominantly dominated by agriculture [3], and accounts for about $40 \%$ of the Gross Domestic Product (GDP) and employs two third of the labour force [4].

The National and International Research Institute (NIRI) in Nigeria have developed over 52 varieties of rice with potential yield of 2 - 8 tonnes paddy per hectare and maturity period ranging from 95 - 140 days [5]. Nevertheless, domestic production of rice in Nigeria is not meeting the Nigerians' demand [6] and may be partly due to the huge import bill on rice in the nation. Demand for rice has been increasing at much faster rate in Nigeria than in other West African countries since the mid 1970s. Nigeria's per-capita rice consumption level has grown significantly at $7.3 \%$ per annum, rising from about 3.0 kilograms in the $1970 \mathrm{~s}$, to $18 \mathrm{~kg}$ in the $1980 \mathrm{~s}$, to $22 \mathrm{~kg}$ in 1990s [4], to $22.0 \mathrm{~kg}$ at 3.0 million metric tonne as deficit in the 1999 [7]. In addition, small-holder farmers dominated rice production in Nigeria with 0.5 - 1.5 hectares per farmer using manual labour for virtually all its operations.

Despite the seemingly bright employment and poverty reduction potentials of rice production and marketing, families with low income are prevalent in Nigeria as over $70 \%$ are poor [8]. Consequently, majority of the rice traders cannot conveniently make the product available to consumers at the right time and at a profit margin required to keep them in operations [9]. Nigerians prefer the local rice because of its agreeable taste and smell [10]. Farmers including women farmers face enormous pressures as the nation integrates more into the world economy. Apart from women involving in the carious chains of economic activities in the Nigerian rice industry like harvesting, parboiling, drying, milling/threshing etc., they also embark on the production of rice. Rahman et al. state that, women play vital role in food production processing and marketing in Nigeria such as rice production; producing about 60 - 80 percent of total output [11]. Although, Umeh \& Ataborh observed that, rice producers are dominated by males which accounts for $85.8 \%$ while women accounts for only $14.2 \%$ [4].

Nigerian women have made considerable contribution to agricultural production and have been found in the production of crops such as yam, maize, cassava, rice and other food crops and also now constituting the majority of smallholder farmers in many parts of the nation such as in the South West, South East, South among others, providing most of the labour and managing many farms on a daily basis [12]. It is however observed that, the impact of both external and internal factors, can affect women farmers [13], which could individually and jointly influence their performance. Most importantly, self-sufficiency in rice production has eluded Nigeria for a long time despite the effort made by the Government of Nigeria for over 36 years towards realizing self sufficiency [4].

Despite the immense contributions of women to agriculture, various findings have reported that women farmers generally, and particularly in Nigeria have some challenges such as, lack access to adequate productive resources such as land, credit, agricultural inputs, education, extension services, and appropriate technology, due to various socio-economic factors [14]. In addition, Ajayinoted that, in spite of the suitable weather and enormous manpower and available facilities for the cultivation of rice, Nigeria is not yet among the world leading rice producers due to the challenges faced by rice farmers especially women rice farmers in Nigeria and how these challenges are affecting their productivity negatively [15]. Watson also, clearly noted that, women-owned farmers perform less than men owned farmers, because they are combated with various challenges that have negative influences on their performances [16].

This has made gender issue become a critical cross-cutting factor in innovation process to promoting equity and enhancing the relative access of farmers to necessary resources through programmes targeted at promoting household food security and poverty reduction [17] and also gender equity. Access to and source of finance and credit is another major issue as women farmers need credit to be able to increase their production in the development of Agriculture. [18]. Lack of access to credit has impede farmers especially women farmers productivity and performances. Nsien opined that credit provision is a useful tool for empowering women and the poor/less privileged, as well as for poverty alleviation [19]. To this end, this study seeks to investigate constraints faced by women farmers growing rice in Nigeria. In connection to this objective, the following research questions would guide the study:

1) What is the level of productivity of women rice farmers in Ekiti State, Nigeria?

2) What are the major sources of support for women rice farmers in Ekiti State, Nigeria?

3) What are the major constraints affecting women rice farmers productivity in Ekiti State, Nigeria? 


\section{Background to the Study}

$\mathrm{HO}_{1}$ : There is no significant difference in the productivity among women rice farmers in Nigeria.

$\mathrm{HO}_{2}$ : Sources of support for women rice farmers do not have significant effect on their rice productivity in Nigeria.

$\mathrm{HO}_{3}$ : Problems/constraints encountered by women rice farmers in Nigeria do not have significant influence on their rice productivity.

\section{Previous Studies Section}

In Sub-Saharan Africa countries, women play active part and rely on their income from rice to meet variety of personal and household needs [20] [21]. Many women in developing economies such as Nigeria have become involved in rice production irrespective of their economic and social backgrounds. Apart from the need to earn wages and become financially independent, women see rice production as a means of employment because majority of them are not adequately educated for white-collar jobs, which in any case are not readily available. Rice cultivation is also a means to fight hunger. In addition, some women (10\%) reported that they became rice farmers simply because they got married to rice farmers, while some were motivated by others [21]. These reasons are closely related to the socio-economic profile of the individual farmers and the economic realities of the country.

Female rice cultivators in developing countries such as Nigeria fall mostly within the age brackets 20-25 years and above $40 \mathrm{~s}$ stages of life [21]. This is the period when women tend to shoulder more reproductive and/or productive responsibilities as mothers, single parents or widows. The fact that most of them (64\%) are married and 54\% have between 6 to 10 persons in their households, justifies their involvement in rice cultivation. Rice production was a solution introduced by women to tackle their general problems of economic dependency and hardship. In other words, bargaining over who does what in the process of rice production does not take place in a vacuum. It is closely influenced by the historical context, social norms, and differential access to resources and opportunities by men and women [21]-[23].

Ayoola et al. observed that, the gross margin profit for male farmers was N117 820.00 and was observed to be significantly affecting their productivity while for female farmers, their gross margin was N76 165.00 and did not have significant effect on their productivity [6]. This revealed that, productivity of males was more than their female counterparts and the males were able to maximize their profit better than the female rice farmers. In addition, Ojo, in his study, technical efficiency of rural women farmers in Borno State, Nigeria, observed that, determinants of technical efficiency among rural women farmers were education, off farm income, time on farm, age, credit and land ownership, which would possibly increase the farmers productivity [12].

In respect to the sources of financial resources by farmers, Balogun et al. revealed that, less than half (44.1\%) of the credit needs of households which also include farmers considered in their study were met through the help of friends/family and cooperatives sources [9]. These financial sources offer households greater access to credit in terms of volume, pay-back period and interest rates. In another study, Adebayo \& Adeolaalso investigated the sources and uses of agricultural credit among small-scale farmers in Oyo State [24]. The study revealed that, cooperative societies was the highest source of farmers' credit (84.7\%), followed by personal savings, friends/relatives (62.5\%). In addition, 60\% have their credit source from esusu clubs (traditional savings association).

Of the constraints affecting rice farmers, the cost of rice, the taste and its nutritive value explain the shift in consumer preference from other traditional food crops to rice in West Africa such as Nigeria. This has also made farmers to intensify rice production due to shift in the consumption pattern of households. According to WARDA, the most important factors contributing to the shift in consumer preferences from traditional staples to rice are rapid urbanization and associated changes in family occupational structures [25]. This is because rice is easy to prepare, takes relatively less cooking time, and it is also easy to handle and serve.

In addition, Amaza et al. found that lack of awareness due to low literacy rate hinders women's access to farm resources in Nigeria and thus affect their productivity [26]. Rice farmers are also affected by several factors including poor access to good quality seed, fertilizers and agrochemicals, poor producer prices, lack of mechanized equipments for threshing and winnowing which reduces quality of paddy rice, increases labour cost; lack of access to credit and market information. Improved access of farmers to these resources would likely increase farm productivity and reduce production costs; thereby increasing the competitive capacity of rice farmers [6].

Furthermore, the efficiency factors affecting the productivity of the female farmers include farming expe- 
rience, marital status, number of extension visits and household size [6]. Age related negatively with efficiency of productivity but was not significant in Olagunju et al.' work [27]. Nevertheless, Ayoola et al. observed that, age would influence rice production negatively, implying that the older the rice farmers the less the vigour for farming. Other variables such as farming experience, educational level, land, marital status and total variable cost influence rice production positively, implying that rice production could be increased by increasing the use of land and variable inputs such as fertilizers, herbicides and labour [17].

According to Phillip, Nkonya, Pender \& Oni, the various constraints to agricultural development and productivity in Nigeria which also cuts across women rice productivity are poor agricultural pricing policies, low fertilizer use, low access to agricultural credit, low and unstable investment in agricultural research, poor funding and coordination of agricultural extension, land tenure system and land degradation and poor market access and marketing efficiency [28]. Ndanitsa et al. reported that some of the constraints faced by farmers were those of poor rural infrastructure, limited capital to increase volume of coverage, lack of trained man-power, low level of educational status, and lack of availability of extension education [29]. These factors have jointly led to the large gap observed in rice demand and domestic production over the years [30]. In addition, the demand for rice had risen steadily while domestic production increased at a much lower rate and it is a little wonder that the demand will still increase due to the expected increase in population by over 50 percent between the years 2000 and 2020 [31].

\section{Theoretical Underpinning}

Many studies have addressed the provision of facilities and resources for farmers and their effect on farmers' productivity in many countries. Such studies include (in India) [32] [33]; (in Zimbabwe) [34]; in USA [35] among others. In Nigeria, many studies in this respect have also been done [10] [36]-[40].

Women play vital roles in food production, processing and marketing in Nigeria; producing about 60 - 80 percent of total output [11], and contributing about 60 - 80 percent of agricultural labor force [41]. They also contribute more than two-thirds of their produce towards household subsistence [42] [43]. It has been established that in Sub-Saharan Africa which Nigeria is part, there is gender inequality in farmers' access to adequate productive resources such as land, credit, agricultural inputs, education, extension services, and appropriate technology [6]. This has affected their productivity and has resulted in relative inefficiencies in farming systems.

\section{Research Methodology}

The study employed the survey research design. In the South-Western part of Nigeria, Ekiti State remains one of the least developed economically and about 87.0 percent of the state population are farmers, of which "70 percent are actively engaged in rice production" [44]. The study used primary data, which was obtained with the aid of questionnaire. The questionnaire was divided into six sections: Sections A, B, C, D, E, and F consisting of the socio-economic characteristics of women rice farmers, farming information, sources of farm support, resources and inputs used by farmers, productivity of farmer, and challenges or constraints faced by farmers.

The study employed the simple random sampling technique. A sample size of one hundred women rice farmers was used for this study. The questionnaire was subjected to validation using the Cronbach' alpha and a reliability of 0.77 was obtained. This implies that, the instrument was reliable to measure the variables of the study.

Information and data obtained from respondents were subjected to analysis using the descriptive statistic, such as frequency and percentage. In addition, the t-test and regression analysis were used for this study to test for significance and to determine relationship between variables of interest at 0.05 level of significance. The regression analysis was given by:

$$
Y=a+b_{1} X_{1}+b_{2} X_{2} \cdots b_{j} X_{i}+e_{i}
$$

where $Y=$ dependent variable, $a=$ the intercept value of the regression, $b_{1}-b_{\mathrm{j}}=$ are the regression coefficients, $X_{1}-X_{i}=$ the explanatory variable and $e_{i}=$ error term.

In this study, $X_{s}$, which are the independent variables are:

$Y$ : Productivity of Rice Farmers;

$X_{1}$ : Labour Availability; 
$X_{2}$ : Credit Availability;

$X_{3}$ : Faming Experience;

$X_{4}$ : Age;

$X_{5}$ : Educational Level;

$X_{6}$ : Marital Status;

$X_{7}$ : Household size;

$X_{8}$ : Farm Size;

$X_{9}$ : Land Availability;

$X_{10}$ : Sources of Finance.

\section{Result and Discussions of Findings}

\subsection{Productivity of Women Rice Farmers}

The level of productivity of women rice farmers was presented in Table 1. The result showed that, only 26\% have a negative productivity, $53 \%$ had positive productivity, but few (31\%) had a positive profit of above 100,000 Naira, others had a profit of between 1 - 100,000 Naira. This implies that, 26\% of women rice farmers were not making significant profit, and 53\% are making positive performance or productivity on their rice farm, nevertheless, this profit was skewed and favored only about $31 \%$.

\subsection{Sources of Financial Support}

The distribution of women rice farmers' sources of financial support was presented in Table 2. The result showed that women rice farmers depended mostly on personal savings as $83.7 \%$ admitted that their sources of financial support came from it. Also, 74.5\% also sourced for financial support from farmers association, 78.0\% from families and relatives. Other financial support for women rice farmers are financial institutions (30.1\%), friends (25.3\%), government (16.0\%) and community aids (10\%). This implies that personal saving and farmers associations were the most important services for women farmers' financial supports.

\subsection{Challenges Militating against Women Rice Farmers}

Challenges militating women rice farmers productivity are presented in Table 3 . The result revealed that source of finance was one of the major challenges faced by women rice farmers as $91.7 \%$ attested to this. Credit availability and accessibility was also another important factor (88.4\%). Also, 84.5\%, 84.3\%, 83.7\% and 82.3\% stated that lack of mechanized/technological equipments, level of degradation, poor access to farming/marketing information for easy market penetration, and high cost of farming expenditure respectively were also major challenges facing them, and are thus affecting their productivity.

In addition, availability of fertilizers and other agro-chemicals (61.0\%), poor coordination of agricultural extension officers (57.7\%), poor producer prices (57.5\%), lack of awareness of farm resources (46.3\%) and also low demand for rice (12.8\%) affect their performances and productivity.

Table 1. Distribution of productivity by women rice farmers.

\begin{tabular}{lcc}
\hline & Frequency & Percent \\
\hline Negative Productivity & 26 & 26.0 \\
Zero Productivity & 1 & 1.0 \\
Positive Productivity & 53 & 53.0 \\
1 - 5000 Naira & 9 & 9.0 \\
5001 - 20,000 Naira & 6 & 6.0 \\
20,000 - 50,000 Naira & 5 & 5.0 \\
50,000 - 100,000 Naira & 2 & 2.0 \\
Above 100,000 Naira & 31 & 31.0 \\
Missing Values & 20 & 20.0 \\
Total & 100 & 100.0 \\
\hline
\end{tabular}


Table 2. Distribution of sources of financial support for women rice farmers.

\begin{tabular}{|c|c|c|}
\hline Sources & Frequency & Percent \\
\hline \multicolumn{3}{|c|}{ Personal savings } \\
\hline Yes & 82 & 83.7 \\
\hline No & 16 & 16.3 \\
\hline Total & 98 & 100.0 \\
\hline \multicolumn{3}{|c|}{ Financial institutions } \\
\hline Yes & 28 & 30.1 \\
\hline No & 65 & 69.9 \\
\hline Total & 93 & 100.0 \\
\hline \multicolumn{3}{|l|}{ Friends } \\
\hline Yes & 24 & 25.3 \\
\hline No & 71 & 74.7 \\
\hline Total & 95 & 100.0 \\
\hline \multicolumn{3}{|c|}{ Families and relative } \\
\hline Yes & 76 & 78.0 \\
\hline No & 19 & 22.0 \\
\hline Total & 95 & 100.0 \\
\hline \multicolumn{3}{|c|}{ Government } \\
\hline Yes & 16 & 16.0 \\
\hline No & 84 & 84.0 \\
\hline Total & 100 & 100.0 \\
\hline \multicolumn{3}{|c|}{ Farmers association } \\
\hline Yes & 73 & 74.5 \\
\hline No & 20 & 21.5 \\
\hline Total & 93 & 100.0 \\
\hline \multicolumn{3}{|c|}{ Community aids } \\
\hline Yes & 10 & 10.6 \\
\hline No & 84 & 89.4 \\
\hline Total & 94 & 100.0 \\
\hline
\end{tabular}

\subsection{Test for Hypothesis}

\subsubsection{Hypothesis One}

The $t$-test result for hypothesis $\mathrm{HO}_{1}$, was presented in Table 4. The result showed that the $t$-value was -1.974 with a $p$-value of 0.05 . This implied that the hypothesis $\mathrm{HO}_{1}$ which stated that there is no significant difference among women rice farmers productivity in Nigeria was rejected $(t$-value $=-1.974 ; p=0.05)$. Thus, there was a significant difference among women rice farmers productivity in Nigeria.

\subsubsection{Hypothesis Two}

The regression analysis for hypothesis two is presented in Table 5. The result revealed that only government 
Table 3. Distribution of challenges.

\begin{tabular}{|c|c|c|}
\hline & Frequency & Percent \\
\hline \multicolumn{3}{|c|}{ Sources of finance } \\
\hline Yes & 88 & 91.7 \\
\hline No & 8 & 8.3 \\
\hline Total & 96 & 100.0 \\
\hline \multicolumn{3}{|c|}{ Credit availability and accessibility } \\
\hline Yes & 84 & 88.4 \\
\hline No & 11 & 11.6 \\
\hline Total & 95 & 100.0 \\
\hline \multicolumn{3}{|c|}{ Farming expenditure } \\
\hline Yes & 79 & 82.3 \\
\hline No & 17 & 17.7 \\
\hline Total & 96 & 100.0 \\
\hline \multicolumn{3}{|c|}{ Low demand for rice } \\
\hline Yes & 12 & 12.8 \\
\hline No & 82 & 87.2 \\
\hline Total & 94 & 100.0 \\
\hline \multicolumn{3}{|c|}{ Lack of awareness of farm resources } \\
\hline Yes & 43 & 46.3 \\
\hline No & 52 & 54.7 \\
\hline Total & 95 & 100.0 \\
\hline \multicolumn{3}{|c|}{ Poor access to good quality seed } \\
\hline Yes & 54 & 60.7 \\
\hline No & 35 & 39.4 \\
\hline Total & 89 & 100.0 \\
\hline \multicolumn{3}{|c|}{ Poor producer prices } \\
\hline Yes & 50 & 57.5 \\
\hline No & 37 & 42.5 \\
\hline Total & 87 & 100.0 \\
\hline \multicolumn{3}{|c|}{ Lack of mechanized/technological equipments } \\
\hline Yes & 71 & 84.5 \\
\hline No & 13 & 15.5 \\
\hline Total & 84 & 100.0 \\
\hline \multicolumn{3}{|c|}{ Poor access to farming/market information for market access } \\
\hline Yes & 72 & 83.7 \\
\hline No & 14 & 16.3 \\
\hline Total & 86 & 100.0 \\
\hline \multicolumn{3}{|c|}{ Poor coordination of agric extension officers } \\
\hline Yes & 49 & 57.7 \\
\hline No & 36 & 42.3 \\
\hline Total & 85 & 100.0 \\
\hline \multicolumn{3}{|c|}{ Low degradation } \\
\hline Yes & 70 & 84.3 \\
\hline No & 13 & 15.7 \\
\hline Total & 83 & 100.0 \\
\hline
\end{tabular}


Table 4. $t$-test result for hypothesis one.

\begin{tabular}{lccccccc}
\hline & N & Df & Mean & Std. dev & $\boldsymbol{t}$-Value & $\boldsymbol{p}$-Value & Significance \\
\hline Women rice productivity & 80 & 79 & $-1.58 \mathrm{E} 6$ & 6.88 & -1.974 & 0.05 & Significant \\
\hline
\end{tabular}

Table 5. Regression analysis for sources of financial support.

\begin{tabular}{ccccccc}
\hline & B & Std. Error & Beta & $\boldsymbol{t}$-Value & $\boldsymbol{p}$-Value & Significance \\
\hline Constant & 2699347.6 & 2553306.3 & & 1.057 & 0.29 & N.S \\
Personal saving & 504274.9 & 602402.2 & 0.14 & 0.837 & 0.41 & N.S \\
Financial institutions & -344025.6 & 656060.1 & -0.09 & -0.524 & 0.60 & N.S \\
Friends & 1023594.9 & 710124.7 & 0.24 & 1.441 & 0.15 & N.S \\
Government & -177279 & 7273325.2 & -0.36 & $-2.451^{* *}$ & 0.02 & S \\
Families \& relatives & -245163.7 & 7011561.3 & -0.05 & 0.349 & 0.73 & N.S \\
Farmer's association & 248975.2 & 639334.2 & 0.051 & 0.389 & 0.70 & N.S \\
Community aids & -231725.9 & 700197.5 & -0.04 & -0.331 & 0.74 & N.S \\
\hline
\end{tabular}

Dependent variable: Women rice farmers' productivity; N.S-Not significant; S-Significant; ${ }^{* *}=5 \%$ level of significance.

support as a source was negatively significant as it affected women rice farmers' productivity negatively ( $t$-value $=-2.451 ; p<0.05)$. Nevertheless, other financial support sources were not significant $(p>0.05)$. Also, the ANOVA result for the joint effect of the women rice farmers do not show a significant effect on their productivity $(F=1.040 ; p>0.05)$.

\subsubsection{Hypothesis Three}

The regression analysis result to hypothesis three is provided in Table 6. The result confirmed that only labour availability, credit availability and farming experience were significant. Labour availability was negatively significant $(t$-value $=-2.31 ; p<0.05)$ and credit availability was also negatively significant $(t$-value $=2.53 ; p<$ $0.05)$. Nevertheless, farming experience was positively significant $(2.35 ; p<0.05)$. This implies that labour availability and credit availability have influenced women rice farmers' productivity negatively, while farming experience had influenced them positively.

The effect of the joint challenges on women rice farmers was presented in Table 7 and the result showed that, all challenges have not had significant effect on women rice farmers' performances $(F=1.597, p>0.05)$.

\section{Discussions of Findings}

The result of this study a high percentage made positive performance or productivity, however this performance was skewed to favor only about 31\%. This bolstered the findings of Ayoola et al. that, the gross margin for farmers productivity was low and thus could not be maximized to have significantly effect on their productivity [6]. The result showed that personal saving and farmers associations were the most important services and sources for women farmers' financial supports. This implies that in Nigeria, women play an active part and rely on their income from rice to meet a variety of needs. This revealed that, majority used their income or earnings from rice to support themselves. The result from this findings contrasts Balogun et al.' result that, friends/family and cooperatives sources offer households greater access to credit in terms of volume, pay-back period and interest rates [9]. The findings from this study bolstered the work of Adebayo \& Adeola that, dependence on co-operative societies for agricultural credit was the highest source of farmers' credit, followed by personal savings, friends/relatives, $60 \%$ have their credit source from esusu clubs (traditional savings association), while money lending and credit from produce buyers accounted for $33.3 \%$ of the sources used by the respondents for agricultural credit [24].

The study also revealed that sources of finance was one of the major challenges facing women rice farmers 
Table 6. Regression analysis for challenges facing women rice farmers.

\begin{tabular}{ccccccc}
\hline & B & Std. Error & Beta & $t$-value & $p$-value & Significance \\
\hline Constant & 862699.5 & 2110299.8 & & 0.409 & 0.68 & \\
Labour availability & -1322206.2 & 572187.4 & -0.33 & $-2.31^{* *}$ & 0.03 & $\mathrm{~S}$ \\
Credit availability & 1166478.1 & 461940.9 & -0.350 & $-2.53^{* *}$ & 0.02 & $\mathrm{~S}$. \\
Farming experience & 132742.5 & 376720.8 & 0.05 & $2.35^{* *}$ & 0.03 & $\mathrm{~S}$. \\
Age & -274812.4 & 420822.7 & -0.09 & -0.65 & 0.52 & N.S \\
Educational level & -32665.2 & 318719.3 & -0.02 & -0.10 & 0.92 & N.S \\
Marital status & -1598.0 & 526218.8 & -0.008 & -0.003 & 0.97 & N.S \\
Household size & -154297.7 & 680489.5 & -0.008 & -0.24 & 0.81 & N.S \\
Farm size & -62252.7 & 495383.9 & -0.03 & -0.13 & 0.90 & N.S \\
Land availability & 222649.2 & 642750.3 & 0.11 & 0.35 & 0.73 & N.S \\
Sources of finance & 140179.1 & 678253.8 & 0.06 & 0.21 & 0.84 & N.S \\
\hline
\end{tabular}

Dependent variable: women rice farmers’ productivity; Adjusted R2 $=0.12$; N.S = Not significant; ${ }^{* *}=5 \%$ level of significance.

Table 7. ANOVA result of effect of the joint challenges on women rice farmers’ productivity.

\begin{tabular}{ccccccc}
\hline & Sum of square & Df & Mean sq & F & $\boldsymbol{p}$-value & Significance \\
\hline Regression & 1.193 & 16 & 7.456 & & & \\
Residual & 2.428 & 52 & 4.669 & 1.597 & 0.103 & Not significant \\
Total & 3.621 & 68 & & & \\
\hline
\end{tabular}

productivity. Credit availability and accessibility were other important factor. Also, lack of mechanized/technological equipments, level of degradation, poor access to farming/marketing information for easy market penetration, and high cost of farming expenditure respectively were also major challenges faced by women rice farmers, and are thus affecting their productivity. In addition, availability of fertilizers and other agro-chemicals, poor coordination of agricultural extension officers, poor producer prices, lack of awareness of farm resources and also low demand for rice were also challenges facing women rice farmers. There was a significant difference among women rice farmers productivity in Ekiti, Nigeria.

The result showed that government support as a major source of farmers' support affected women rice farmers' productivity negatively while other financial support sources were not significant. Also there was no joint effect of financial sources of women rice farmers on their productivity. In addition, labour availability and credit availability had influenced women rice farmers' productivity negatively, while farming experience had influenced them positively. This implies that both external and internal factors can affect women farmers. The result of this study also concur with the findings of Rahman who noted that, despite the immense contributions of women to agriculture, women farmers generally, and particularly in Nigeria, lack access to adequate productive resources such as land, credit, agricultural inputs, education, extension services, and appropriate technology, due to various socio-economic factors had affected women rice farmers productivity [11]. This could buttressed why Ajayi noted that, in spite of the suitable weather and enormous manpower and available facilities for the cultivation of rice, Nigeria is not yet among the world leading rice producers due to the challenges faced by rice farmers especially women rice farmers in Nigeria and how these challenges are affecting their productivity negatively [15]. This also buttressed Watson who clearly noted that, women-owned farmers perform less than men owned farmers, because they are combated with various challenges that have negative influences on their performances [16].

In addition, this study bolstered Amaza et al. that lack of awareness due to low literacy rate hindered women's access to farm resources in Nigeria and thus affect their productivity [26]. It could be that, women rice farmers 
are not fully aware of credit availability or/and how to access them and thus affecting them negatively. The study also buttressed the findings of Ayoola et al. that, rice farmers including women rice farmers are also affected by several factors including poor access to good quality seed, fertilizers and agrochemicals, poor producer prices, lack of mechanized equipments for threshing and winnowing which reduces quality of paddy rice, increases labour cost; lack of access to credit and market information [32]. In addition, the findings of this study bolstered the findings of Ndanitsa et al. who reported that some of the constraints faced by farmers were those of poor rural infrastructure, limited capital to increase volume of coverage, lack of trained man-power, level of educational status, and availability of extension education [29].

Age, educational level, land availability, marital status, household size and others were not significant in this study. This contrasts the findings of WARDA [25], and Ayoola et al. [6] that the efficiency factors affecting the productivity of the female farmers include farming experience, marital status, number of extension visits and household size. The result showed that, all challenges have not had significant effect on women rice farmers' performances. This contrast Kazeem who stated that, challenges affecting rice farmers' productivity have jointly led to the large gap observed in rice demand and domestic production over the years as the result of this study does not show a joint effect of these challenges on women rice farmers in Nigeria [30].

\section{Conclusion and Recommendation}

In conclusion, major sources of financial resources for women rice farmers were personal saving and farmers associations. Also, only credit availability and poor access to quality seed were observed to affect women rice farmers productivity, howbeit in a negative form. In addition, all challenges have not had significant effect on women rice farmers' productivity. Productivity among rice farmers was skewed to a little few. Various recommendations provided by this study include:

- Women rice farmers should endeavour to undergo and attend various developmental programmes to develop themselves so as to increase their competitive advantage in their locality and also in the local and global agricultural sector.

- Governments and other policy makers should strategize plans and programmes that would contribute to women rice farmers, agricultural, community and national development. These programmes should train, equip and provide necessary information about access to resources such as financial resources.

- Also, the provision of credit facilities and schemes should also be made available for farmers especially women rice farmers so as to enhance the potentials of their productivity leading to personal, family, community and national development.

- Governments should also try to provide necessary resources that could be of importance to women rice farmers' access to such resources such as availability of fertilizers, quality seed provision, provision of farm mechanisms and technology.

- In addition, awareness programmes to create awareness for information provision to women rice farmers such as agricultural information, weather information, marketing/market information, and other information necessary for their productivity should also be provided not only by governments but other private organizations.

- There should be attention given to research and development in respect to agricultural sciences and also employing agricultural extension officers/agents who would go and present such information to women rice farmers to enhance their productivities and also agricultural productivity in Nigeria.

- The government and private organization should also partner together to bring about positive change on women rice farmers development and also enhancing their productivity.

- The government should also provide a policy that could make foreign investors to come and invest in the Nigeria farming system especially in increasing the chances of women rice farmers in the Nigeria agricultural sector so as to improve their productivity and that of the economy.

- Also, foreign bodies attracted to developing women or women rice farmers should also see the agricultural sector as a major part of entrepreneurship development and also see women in agriculture as women in entrepreneur and invest in them to enhance their potential for success, productivity and their competitive advantage over their male counterpart and also among other businesses.

\section{References}

[1] Hauser, E. (2003) The WTO Food Security and Poverty Reduction—A Contradiction in Terms? 2nd Edition, Agricul- 
ture and Rural Development, Swaziland Printing and Publishing Company Limited, 8-11.

[2] Akande, T. (2003) The Rice Sector in Nigeria. United Nation Crop Project (UNCP) Country Agricultural Project on Trade Liberalization in Agricultural Sector and the Environment, Geneva, 10. In: Reference [4]. http://www.ifmaonline.org/pdf/congress/07Umeh\&Ataborh.pdf

[3] Nigerian Population Census (2006) National Population Commission, Federal Republic of Nigeria. http://www.nigeriamasterweb.com/Nigeria06CensusFigs.html

[4] Umeh, J.C. and Ataborh, E.M. (2006) Efficiency of Rice Farmers in Nigeria: Potentials for Food Security and Poverty Alleviation. http://www.ifmaonline.org/pdf/congress/07Umeh\&Ataborh.pdf

[5] Ogundari, K. (2006) Determinants of profit Efficiency among Small-Scale Rice Farmers in Nigeria: A Profit Function Approach. Paper Presented at International Association of Agricultural Economists Conference, Gold Coast, 12-18 August 2006, 2.

[6] Ayoola, J.B., Kudi, T.M., Dangbegnon, C., Daudu, C.K., Mando, A., Amapu, I.Y., Adeosun, J.O. and Ezui, K.S. (2012) Gender Perspectives of Action Research for Improved Rice Value Chain in Northern Guinea Savanna, Nigeria. Journal of Agricultural Science, 4, 211-218. www.ccsenet.org/jas

[7] Ologbon, O.A.C., Ikheloa, E.E. and Akerele, E.O. (2012) Adoption of “Ofada” Rice Variety and Technical Efficiency of Rice-Based Production Systems in Ogun State, Nigeria. World Journal of Agricultural Sciences, 8, 624-631.

[8] National Economic Empowerment and Development Strategy (NEEDS) (2007) The NEEDS Secretariat, National Planning Commission. Federal Secretariat, Government Press, Abuja, Nigeria.

[9] Balogun, O.L., Akinlade, R.J. and Campbell, O.A. (2012) Impact of Microfinance on Rural Households. Cooperative Finance in Developing Economies, 2012 International Year of Cooperatives. Soma Prints Ltd., Lagos.

[10] Longtau, S.R. (2000) Multi-Agency Partnership in West African Agriculture: A Review and Description of Rice Production System in Nigeria. Monograph, Ecosystem Development Organization, Jos, 47 p.

[11] Rahman, S.A., Gabriel, J. and Marcus, N.D. (2004) Gender Differentials in Labour Contribution and Productivity in Farm Production. Empirical Evidence from Kaduna State of Nigeria. The National Conference on Family, Makurdi, 1-5 March 2004.

[12] Ojo, C.O. (2012) Technical Efficiency of Rural Women Farmers in Borno State, Nigeria. Developing Country Studies, 2, 61-67. http://www.iiste.org/

[13] Mahmood, R. and Hanafi, N. (2012) Entrepreneurial Orientation and Business Performance of Women-Owned Small and Medium Enterprises in Malaysia: Competitive Advantage as a Mediator. International Journal of Business and Social Science, 4, 82-90.

[14] Rahman, S.A. (2008) Women's Involvement in Agriculture in Northern and Southern Kaduna State, Nigeria. Journal of Gender Studies, 17, 17-26. http://dx.doi.org/10.1080/09589230701838347

[15] Ajayi (1998) Small Scale Farming in Nigeria: Problems and Prospect. The National Workshop on Strategies for Increasing the Agricultural Productivity of Nigerian Women, National Productivity Centre (NPC), 21-23 July.

[16] Watson, J. (2003) SME Performance: Does Gender Matter? The Small Enterprise Association of Australia and New Zealand 16th Annual Conference, Ballarat, 28 September-1 October 2003, Paper No. 32, 1.

[17] Ayoola1, J.B., Dangbegnon, C., Daudu, C.K., Mando, A., Kudi, T.M., Amapu, I.Y., Adeosun, J.O. and Ezui, K.S. (2011) Socio-Economic Factors Influencing Rice Production among Male and Female Farmers in Northern Guinea Savanna Nigeria: Lessons for Promoting Gender Equity in Action Research. Agriculture and Biology Journal of North America, 2, 1010. http://www.scihub.org/ABJNA

[18] Olowa, O.W. and Olowa, O.A. (2011) Issues, Problems and Policies in Agricultural Credit: A Review of Agricultural Credit in Nigeria. Bangladesh e-Journal of Sociology, 8, 87-108.

[19] Nsien, G.F. (2000) A Survey on the Use of Micro-Credit in the Empowerment of Nigerian Women. University of Nigeria Research Publications.

[20] FAO (1984) Grasroots Training for Swamp Rice Development. Manual on Swamp Construction. TCP/SIL/2304(T), FAO, Rome.

[21] Fonjong, L.N. and Athanasia, M.F. (2007) The Fortunes and Misfortunes of Women Rice Producers in Ndop, Cameroon and the Implications for Gender Roles. Journal of International Women's Studies, 8, 133-147.

[22] Sen, A. (1990) Gender and Cooperative Conflict. In: Tinker, I., Ed., Persistent Inequality, Oxford University Press Oxford, 123-148.

[23] Agawal, B. (1997) “Bargaining” and Gender Relations: Within and Beyond the Household. Feminist Economics, 3, 151.

[24] Adebayo, O.O. and Adeola, R.G. (2008) Sources and Uses of Agricultural Credit by Small-Scale Farmers in Surulere 
Local Government Area of Oyo State. Anthropologist, 10, 313-314.

[25] WARDA (2003) Rice in West Africa.

[26] Amaza, P.S., Kwagbe, P.V. and Amos, A.A. (1999) Analysis of Women's Participation in Agricultural Cooperatives: Case Study of Borno State, Nigeria. Annals of Borno, 15-16, 187-196.

[27] Olagunju, F.I., Fakayode, S.B., Babatunde, R.O. and Ogunwole-Olapade, F. (2013) Gender Analysis of Sweet Potato Production in Osun State, Nigeria. Asian Journal of Agricultural Extension, Economics \& Sociology, 2, 1-13.

[28] Dayo, P., Ephraim, N., John, P. and Ayoola, O.O. (2009) Constraints to Increasing Agricultural Productivity in Nigeria: A Review. Nigeria Strategy Support Program (NSSP) Background Paper No. NSSP 006, September 2009.

[29] Ndanitsa, M.A., Musa, S.A. and Umar, I.S. (2011) Impact of Microfinance Institutions’ Micro-Credit Program on Poverty Alleviation through Agricultural Finance Intermediation to Maize Farmers in Niger State, Nigeria. Savannah Journal of Agriculture, 6, 82-92.

[30] Kazeem, M.A. (1991) Economics of Rice Production in Lagos State: A Case Study of Itoikin Irrigation Project, Epe, Lagos State. Unpublished M.Sc. Thesis, Department of Agricultural Economics, University of Agriculture, Abeokuta.

[31] Alfred, S.D. (2002) Socio-Economic Factors Affecting Rice Production by Women Farmers in Ondo State. The Ogun Journal of Agricultural Sciences, 151-165. In: Ologbon, O.A.C., Ikheloa, E.E. and Akerele, E.O. (2012) Adoption of "Ofada” Rice Variety and Technical Efficiency of Rice-Based Production Systems in Ogun State, Nigeria. World Journal of Agricultural Sciences, 8, 624-631.

[32] Rajasekhar, D. (2004) Institutional Finance for Agriculture Analysis at Micro and Macro Levels. Ph.D. Thesis, University of Mysore, Mysore.

[33] Devi, R.U. and Govt, S.R.K. (2012) The Role of Credit Co-Operatives in the Agricultural Development of Andhra Pradesh, India. International Journal of Cooperative Studies, 1, 55-64.

[34] Bratton, M. (1986) Financing Smallholder Production: A Comparison of Individual and Group Credit Scheme in Zimbabwe. Public Administration and Development, 6, 115-132. http://dx.doi.org/10.1002/pad.4230060202

[35] Ellinger, P.N. and Barry, P.J. (2004) A Farmer's Guide to Agricultural Credit; A Publication of the Centre for Farm and Rural Business Finance: A finance-Focused Initiative Providing Information to Farm and Rural Businesses and their Knowledge Providers. University of Illinois, Urbana Champaign.

[36] Adegbite, D.A., Oloruntoba, A.O. and Olaoye, O.J. (2009) Performance Assessment of Ogun State Agricultural and Multi-Purpose Credit Agency (OSAMCA) in Credit Delivery and Operation (2004-2006). Journal of Sustainable Development in Africa, 10, 127-153.

[37] Badiru, I.O. (2010) Review of Small farmer Access to Agricultural Credit in Nigeria. Nigeria Strategy Support Program. Policy Note 25. International Food Policy Research Institute (IFPRI).

[38] Anyiro, C.O. and Oriaku, B.N. (2011) Access to and Investment of Formal Micro Credit by Small Holder Farmers in Abia State, Nigeria. A Case Study of Absu Micro Finance Bank, Uturu. Journal of Agricultural Sciences, 6, 69-76.

[39] Odebiyi, O.C. and Olaoye, O.J. (2012) Small and Medium Scale Aquaculture Enterprises (SMES) Development in Ogun State, Nigeria: The Role of Microfinance Banks. Libyan Agriculture Research Center Journal International, 3, $1-6$.

[40] Ashaolu, O.F., Momoh, S., Phillip, B.B. and Tijani, I.A. (2011) Microcredit Effect on Agricultural Productivity: A Comparative Analysis of Rural Farmers in Ogun State, Nigeria. International Journal of Applied Agricultural and Apicultural Research, 7, 23-35.

[41] Mgbada, J.U. (2000) Production of Staple Crops by Rural Women in Enugu and Ebonyi States. Lessons for Enhancing Poverty Alleviation Programmes. Proceedings of the 6th Annual National Conference of the Agricultural Extension Society of Nigeria, 10-12 April 2000, Ibadan, 11.

[42] Ayoola, J.B. (1999) Economic Analysis of Women Entrepreneurship in Low-Income Households of Benue State, Nigeria. Ph.D. Thesis, Department of Agricultural Economics, Abubarkar Tafawa Balewa University, Bauchi.

[43] Rahman, S.A. and Usman, J.I. (2004) Comparative Analysis of Women’s Participation in Agricultural Production in Northern and Southern Kaduna State, Nigeria. Mobilizing Investors for Sustainable Agricultural Research, Development and Production in Nigeria. Proceedings of the 38th Annual Conference of the Agricultural Society of Nigeria, 17-21 October 2004, 105-108.

[44] Nigerian Institute of Social and Economic Research (NISER) (2002) Assessment of the Economic, Social and Environmental Impact of Rice Production in Nigeria within the Trade Libralisation Framework, A Research Paper, 93 p. 


\section{Appendix}

\section{Questionnaire}

Dear respondent,

This questionnaire was designed to study "the major constraints faced by women rice farmers in Nigeria". Your maximum support is highly needed as you fill in relevant information. Information filled will be strictly used for research purpose.

Thanks

\section{Section A: Demographic Characteristics}

1) Age:
a) below 25
b) 26 - 35
c) $36-45$
d) 45 - 55
e) above 55

2) Marital status:
a) Married ( )
b) Single ( )
c) Widowed ( )
d) Divorced/Seperated ( )

3) Level of Educational:
a) no formal education
b) Primary education
c) secondary education
d) tertiary education

e) informal education

4) Level or years of experience:
a) 1 - 5 yrs
b) 5 - 10 yrs
c) above 10 yrs

5) Household size:

\section{Section B: Farming Information}

6) Is land available for your farming activities?

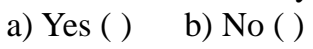

6b) What is the form of land acquisition:
a) purchase ( )
b) Inheritance (
c) Lease/Rentage ( )

7) Farm Size:

8) Do you have labour availability? (Acres)
a) Yes ( )
b) No ( )

9) Do you have available inputs or resources for your farm?
a) Yes ( )
b) No ( )

9b) If No, why ( Give Reason):

10) How is labour for farm activities?
a) Cheap ( )
b) Moderately cheap ( )
c) Costly ( )
d) Very Costly ( )

11) How often do you go to farm?
a) Once a week ( )
b) Twice a week ( )
c) Three Times a week ( )
d) Four Times a week ( )
e) Every day ( )

Section C: Sources of Farm Support

12) What are the sources of support to your farming? (You can tick more than one)

\begin{tabular}{c}
\hline Sources \\
Personal Savings $(\sqrt{ })$ where appropriate \\
Financial Institutions \\
Friends \\
Families and Relative \\
Government \\
Farmers Association \\
Community Aids \\
Others (Please specify them)
\end{tabular}


Section D: Resources and Inputs Used by Farmers

13) What are the inputs/resources used and what are their costs?

\begin{tabular}{|c|c|c|c|c|}
\hline $\mathrm{S} / \mathrm{N}$ & Variable Items & Costs/Month & Fixed Items & Costs/Month \\
\hline i. & Labour & & Land & \\
\hline ii. & Seeds & & Machines/Technology & \\
\hline iii. & Fertilizer/chemicals & & Tools & \\
\hline iv. & Weeding & & Others & \\
\hline v. & Cultivation of Land & & & \\
\hline vi. & Planting & & & \\
\hline vii. & Others & & & \\
\hline
\end{tabular}

\section{Section E: Productivity of Farmers}

14) How much did you realised from your farm products?

15) Where you satisfied with the output from your farm?
a) Yes ()
b) No ( )

16) If No, why?

17) If yes, to what level are you satisfied with the output of your farm?
a) Not Satisfied ( )
b) Satisfied ( )
c) Moderately Satisfied ( )
d) Very Satisfied ( )

Section F: Challenges or Constraints Faced by Farmers (You Can Choose More Than One)

18) What are the challenges that are facing you in rice production? Please tick $(\sqrt{ })$ the ones you know it affects your farming productivity.

\begin{tabular}{c} 
Items \\
Sources of finance \\
Credit availability \\
Availability of finance \\
Farming expenditures \\
High Demand for rice \\
Lack of awareness to farm resources \\
Poor access to good quality seed \\
Poor producer prices \\
Lack of mechanized/technological equipments \\
Access to market information \\
Use of fertilizers and other Agrochemicals \\
Poor agricultural pricing policies \\
Poor funding \\
Poor coordination of agricultural extension \\
\hline
\end{tabular}

